\title{
SATISFACTION LEVEL OF FACULTY MEMBERS OF STATE RUN AND PRIVATE UNIVERSITIES OF PUNJAB RELATED TO WORK ENVIRONMENT: A COMPARATIVE STUDY
}

\author{
DR. RAMANDEEP SAINI ${ }^{1} \&$ MS. CHANJYOT KAUR ${ }^{2}$
}

Director Principal (officiating) Chandigarh Business School of Administration, Dean International Affairs, Chandigarh Group of Colleges (CGC), Landran, Mohali, Punjab, India

Research Scholar, IKG PTU, Kapurthala, Jalandhar, Punjab, india

\begin{abstract}
In the contemporary world, organisations these days face lot of challenges because of the dynamic environment. The major challenge faced by an organisation today is to satisfy its human resources in order to retain them in the ever changing environment. Human resources are the most valuable assets of an organisation who have abundant job opportunities available to them. Increased productivity and effective results of any organisation is dependent on the satisfaction level of employees and the work environment in which an employee is working. The work environment is a significant factor that influences the satisfaction level of employees and in turn job satisfaction is a significant factor that influences the retention of employees in an organisation. Hence, in order to retain the productive employees of an organisation it is very essential to provide supportive work environment to the employees. So the main objective of the research is to study the satisfaction level of faculty members of State Run and Private Universities of Punjab related to work environment. Quantitative research is done in order to compare the satisfaction level of faculty members of State Run and Private Universities of Punjab. Descriptive analysis and multivariate statistical technique including mean, standard deviation and t-test has been applied for obtaining the results. The study concludes by proposing various suggestions that the educational managers need to apprehend the significance of supportive work environment to maximize the job satisfaction level among the faculty members.
\end{abstract}

KEYWORDS: Dynamic Environment, Challenge, Satisfaction, Work Environment, Retention

Received: Jun 08, 2020; Accepted: Jun 28, 2020; Published: Aug 31, 2020; Paper Id.: IJMPERDJUN2020982

\section{INTRODUCTION}

In today's competitive business world, human resource is the most significant component in the procedure of accomplishing organisational objectives. Employees are required to meet the performance standards set by an organisation in order to ensure their job performance and this can only be attained if the employees are provided with a work environment which allows them to perform to their maximum capacity. Most businesses face difficulties during achievement of objectives because they fail to understand the significance of work environment which is to a larger extent responsible for job satisfaction of employees and in turn the retention of employees in the organisation. Such businesses become internally weak; hence they are not able to gain a competitive edge over the competitors [1].

Effective human resource management and supportive work environment affects the performance of workers, organisation and the progression of entire economy. A work environment is described as the place where an employee operates which constitutes the physical, social and psychological environment. Work environment 
includes all the factors that have a lot of impact on the mind and body of an employee. Broadly, work environment includes the work location, workplace relationship, work culture, rules, policies, processes, structures, system and internal and external environmental factors have a lot of impact on the employee productive capacity and employee job satisfaction. The physical work environment constitutes the components that are related with the employee's ability to connect physically with the workplace. The physical work environment components such as ventilation, temperature, infrastructure, light, noise, furniture design, fire safety measures has a lot of impact on employee productivity [2]. The social work environment includes the social relationship at workplace including interaction with co-workers, subordinates and superiors. The workplace environment positively influences the behaviour of employees. Therefore, the quality of work environment acts as a crucial function to determine the motivation level of employees, productivity, and performance [3]. When the supervisors do not give due respect to the employees which they deserve, the employees become uncomfortable and they do not share any innovative or creative idea with their supervisors [4]. The psychological work environment includes stability of work life, open communication, impartiality, consistency and an environment free from fatigue, monotony, boredom. Factors such as autonomy given to employees, organizational structure, working hours, wages and communication between management and workers affect the satisfaction level of the employees [5]. The association with the organisation affects the behaviour of the employees in the organisational setting such as innovative behaviour, motivation level, interaction with employees, absenteeism and employee retention [6].

The employees work under the physical, social and psychological environment where their work is analysed for increased productivity. The main aim is to create an environment for the employees that remove all the causes of anxiety and frustration. If boredom, fatigue and monotony are minimised from the environment the work performance and satisfaction of the employees can be maximized. Supportive work environment encourage the employees to be happy with their job which influences the growth of an organisation and economy. A happy employee shows better results in terms of performance. If an employee is not satisfied with the job it will lead to employee absenteeism and employee turnover. The organisation has to bear a very high cost of job dissatisfaction such as cost attached with recruiting, selecting and training. Thus, it is essential for the organisations to seriously consider the satisfaction level of employees [7].

Education plays a vital role in one's life because it is considered to be a key to success. Providing higher education is an investment in generating human resources which are learned and produce immense benefits to the country. Education has a lot of effect on an individual's life by providing him with a great chance to live and contribute positively to an organisation and the nation as a whole. The status of an organisational institute is dependent on its capability to recruit, select, develop, maintain and retain talented faculty members. Satisfied faculty members contribute effective teaching and research which lead to a pragmatic educational experience to the students. Satisfaction level of faculty members of colleges can be increased by giving proper attention to supervision, recognition and interpersonal relationships [8]. Like salaries have an important role to play similarly work environment also plays a vital role in attracting and retaining the qualified faculty members [9].

\section{REVIEW OF LITERATURE}

The research work has been done to study the available literature on the impact of work environment on the performance and in turn on the satisfaction level of the employees in different context around the world over the years. This research is gaining a lot of importance because of its impact on the employees, organisations and society. 
[10] said that an organisation can improve its productivity if physical components of work environment are improved because the component of physical environment has a positive impact on productivity and employee satisfaction.

[11] examined the impact of physical and psychosocial components of work environment on worker's performance, job satisfaction and organisational effectiveness. The employees who considered the work environment as encouraging resulted higher on employee performance, job satisfaction and organisational effectiveness. Results specified that components of work environment, interpersonal relations, working condition, trust and support and welfare provisions contributed to organisational effectiveness and worker's job behaviour. The results revealed that psychosocial environment has more influence on organisational effectiveness and worker's job behaviour as compared to the physical environment.

[12] found that if the work environment consists of motivational factors like recognition, appreciation, granting responsibility, opportunity for growth and development then the employees get internal happiness which causes job satisfaction among employees.

[13] found that human interactions and human relations play an important role in the job satisfaction rather than financial incentives where time, management skills and energy are required to improve the organisational performance.

[14] found that comfortable environment helps the employee to focus on his job properly which leads to high employee performance which further leads to better organisational productivity. He also found that an employee who is satisfied from the work environment shows significant output.

[15] stated if the employees negatively perceive the components of work environment and do not find the work environment attractive then their organisational productivity and job satisfaction gets negatively affected. However, if the employees find the work environment safe, trusted and friendly it affects the employees positively which leads to high performance, efficient productivity, organisation commitment and job satisfaction. Hence, [16], [17] demonstrated that in order to have high employee performance and satisfied employees a supportive work environment should be provided.

[18] said that work environment constitutes of physical and behavioural environment. He found that components of behavioural environment significantly affect employee performance and satisfaction than components of physical environment.

[19] found that only supervisor support is not sufficient for improved performance of an employee but additional benefits and well organised physical work environment significantly impact job performance and satisfaction.

[20] said that components of work environment like lighting, colour, noise, air quality, equipment and furniture has a lot of impact on productivity of employees. The employee performance in terms of quality and quantity is influenced by the work environment. Poor work environment causes ineffective employee productivity and also reduces the level of job satisfaction. Therefore, organisations should provide a good work environment to the employees for efficient productivity and increased level of job satisfaction.

[21] stated that a supportive environment or attractive work environment is one that focuses on people and gives the employees opportunity to perform efficiently. Supportive environment and attractive work environment encourage employees to use their competencies, skills and knowledge to work efficiently [22]. 


\section{CONCEPTUAL FRAMEWORK}

Work environment can be defined as the place where the employee is working. All the components of work environment are related and significant for the satisfaction and welfare of the employees. Further the satisfaction of employees influence productivity, effective results and employee retention.

\section{Work Environment Consists of Four Components}

Physical Environment

It consists of lighting, temperature at workplace, ventilation, colour of the wall, location, noise in the department, toilets, machines, etc. All these factors seem to be very ordinary but they have a lot of impact on employee's performance.

\section{Social Environment}

It is the relationship that exist between superior, subordinates, co-workers etc. It consists of management policies and practices, informal communication with co-workers, division of work, preservation of cultural values, teamwork, etc.

\section{Psychological Environment}

It deals with the employee's aptitude, values, attitudes etc. It includes motivation, leadership styles, group formation, moral, employee perception, organisational climate, personality, etc

\section{Job Related Issues}

It includes the core dimension (like flexibility, skill variety, feedback, autonomy, task significance and identity, etc) of job which is responsible for the satisfaction, productivity and performance of employees. Job related issues may also include job rotation, job enlargement and job enrichment. [23]

Job satisfaction is a feeling of contentment that he gets from his job. If an employee is satisfied from his job it will lead to increased productivity, decreased employee absenteeism and turnover, enhance commitment and employee retention.

\section{Job Satisfaction is Affected by Two Main Variables}

\section{Organizational Variables}

Organisation variables are associated to the arrangement inside an organisation and it directly affects job satisfaction. It includes working conditions, compensation, leadership styles, work responsibility, nature of work etc.

\section{Individual Variables}

Individual variables are associated with an individual trait. It contains attitude towards work, leadership, supportive manager style, autonomy at work, future career growth, age, job experience, respect and recognition, etc. [24]

\section{OBJECTIVES OF THE STUDY}

The objectives of the study are:

- To compare the satisfaction level of faculty members of State Run and Private Universities of Punjab related to work environment.

- To identify the best practices that can be adopted by various universities to improve satisfaction level of faculty members related to work environment. 


\section{RESEARCH METHODOLOGY}

Research Design - The present study is descriptive in nature.

Type of Research - The type of research is analytical.

Sampling Unit - Faculty members working in State Run \& Private Universities of Punjab with a minimum of one year of teaching experience and post graduation as their minimum level of education. For purpose of this study, faculty members have been defined as those individuals who have been assigned teaching responsibility in the university.

Sample Size - The sample consists of 150 faculty members among State Run \& Private Universities of Punjab.

Sampling Technique - The sampling technique used for the present study is Stratified sampling.

\section{NEED AND SIGNIFICANCE}

The extensive literature review provides that several researches have been done on job satisfaction. Most of the studies on job satisfaction have been executed to identify the factors influencing the level of job satisfaction. But the respondents included in such studies are employees from industry or business organisations. Job satisfaction has been studied in educational sector also but the scope of the study has been the various government or private owned institutes of other states and countries.

It has been found that no comparative analysis of satisfaction level is being done between State run and Private Universities in Punjab related to work environment. So, there is a need to study the comparison of satisfaction level of faculty members of various State Run and Private Universities of Punjab in order to identify the strategies that can be adopted to secure the talented human resources in reputed educational organizations, as they play an important role in shaping the future of young citizens of our country.

The findings of this research will be of extensive help to the educational administrators as suggestions would be proposed to understand the importance of supportive work environment to maximize the job satisfaction level among the faculty members.

\section{FINDINGS}

Table 1: Descriptive Statistics for Variables Related to Work Environment

\begin{tabular}{|l|l|c|}
\hline \multicolumn{1}{|c|}{ Statements } & Mean & Standard Deviation \\
\hline I was oriented/ inducted with the job when I joined this University. & 3.85 & 1.079 \\
\hline University goals and strategies are clearly communicated to me. & 3.61 & 1.055 \\
\hline The rules, regulations and policies in the University are transparent. & 3.68 & 1.070 \\
\hline The suggestions given by the faculty members are being valued in the University. & 3.67 & 1.008 \\
\hline I am satisfied with how I am involved in decisions concerning my work. & 3.68 & 1.012 \\
\hline I am consulted on important matters that affect my job. & 3.63 & 1.084 \\
\hline I feel that the University cares for my needs appropriately. & 3.65 & 1.087 \\
\hline The disciplinary procedure in the University is acceptable to me. & 3.80 & 1.087 \\
\hline I feel that the contributions of the faculty members are appropriately recognised & 3.72 & 1.081 \\
\hline The work is distributed evenly amongst all faculty members of the same department. & 3.69 & 1.130 \\
\hline Men and Women are provided with equal career opportunities in the University. & 3.99 & 1.068 \\
\hline The faculty members are treated with due respect. & 3.92 & 1.020 \\
\hline I am satisfied with the team spirit in the work environment. & 3.79 & 1.149 \\
\hline My job is guaranteed as long as I want to remain in the University. & 3.99 & 0.990 \\
\hline
\end{tabular}


The Table 1 shows the descriptive statistics for variables related to Work Environment which includes the mean values and standard deviation. The mean of the statement "I was oriented/ inducted with the job when I joined this University" is 3.85 which shows that faculty members have agreed with conducting of orientation/induction programme at the time of joining. The mean of next statement "University goals and strategies are clearly communicated to me" is 3.61 which shows that faculty members have agreed with the clear communication of University goals and strategies. The mean of next statement "The rules, regulations and policies in the University are transparent" is 3.68 which show faculty members have agreed with the transparency of rules, regulations and policies in the University. The mean of next statement "The suggestions given by the faculty members are being valued in the University" is 3.67 which show faculty members have agreed with the value given to the suggestions given by the faculty members. The mean of next statement "I am satisfied with how I am involved in decisions concerning my work is 3.68 which show faculty members have agreed with satisfaction related to involvement in decision-making. The mean of next statement "I am consulted on important matters that affect my job" is 3.63 which show faculty members have agreed with the consultation on important matters that affects the job. The mean of next statement "I feel that the University cares for my needs appropriately" is 3.65 which show faculty members have agreed with the needs being cared appropriately. The mean of next statement "The disciplinary procedure in the University is acceptable to me" is 3.80 which show faculty members have agreed with the acceptance of disciplinary procedure in the university. The mean of next statement "I feel that the contributions of the faculty members are appropriately recognised" is 3.72 which show faculty members have agreed with the recognition received for their contribution. The mean of next statement "The work is distributed evenly amongst all faculty members of the same department" is 3.69 which show faculty members have agreed with the even distribution of work among all faculty members of same department. The mean of next statement "Men and Women are provided with equal career opportunities in the University" is 3.99 which show faculty members have agreed with the provision of equal opportunities to both men and women. The mean of next statement "The faculty members are treated with due respect" is 3.92 which show faculty members have agreed with the treatment of faculty members with due respect. The mean of next statement "I am satisfied with the team spirit in the work environment" is 3.79 which show faculty members have agreed with the team spirit in the work environment. The mean of next statement "My job is guaranteed as long as I want to remain in the University" is 3.99 which show faculty members have agreed with the job security in the university as compared to State Run University.

Table 2: Demographic Analysis of Respondents

\begin{tabular}{|c|c|c|}
\hline Demographic Predictors & $\mathbf{N}$ & Percentage \\
\hline \multicolumn{3}{|c|}{ Type of University } \\
\hline State Run & 75 & 50.0 \\
\hline Private & 75 & 50.0 \\
\hline Total & 150 & 100.0 \\
\hline \multicolumn{3}{|c|}{ Gender } \\
\hline Male & 68 & 45.3 \\
\hline Female & 82 & 54.7 \\
\hline Total & 150 & 100.0 \\
\hline \multicolumn{3}{|c|}{ Age Group } \\
\hline Below 30 Years & 32 & 21.3 \\
\hline $30-40$ Years & 95 & 63.3 \\
\hline 41-50 Years & 19 & 12.7 \\
\hline Above 50 Years & 4 & 2.7 \\
\hline Total & 150 & 100.0 \\
\hline \multicolumn{3}{|c|}{ Marital Status } \\
\hline Married & 85 & 56.7 \\
\hline
\end{tabular}




\begin{tabular}{|l|c|c|}
\hline \multicolumn{3}{|c|}{ Table 3 Contd., } \\
\hline Unmarried Educational Qualification \\
\hline Total & 65 & 43.3 \\
\hline \multicolumn{3}{|c|}{ Designation } \\
\hline Doctorate & 119 & 79.3 \\
\hline Post Graduates & 23 & 15.3 \\
\hline M.Phil & 8 & 5.3 \\
\hline Total & 91 & 100.0 \\
\hline \multicolumn{3}{|c|}{ Total Experience in Years } \\
\hline Assistant Professor & 10 & 60.7 \\
\hline Associate Professor & 150 & 32.7 \\
\hline Professor & 25 & 6.7 \\
\hline Total & 53 & 100.0 \\
\hline Length of Service in the Present University (in years) \\
\hline Less Than 2 Years & 33 & 22.0 \\
\hline 2-6 Years & 36 & 24.0 \\
\hline 7-10 Years & 72 & 46.7 \\
\hline More Than 10 Years & 150 & 100.0 \\
\hline Total & 35 & 23.3 \\
\hline \multicolumn{3}{|c|}{} \\
\hline Below 5 Years & 150 & 100.0 \\
\hline 5-10 Years & 150.7 \\
\hline More Than 10 Years & \\
\hline Total & \\
\hline
\end{tabular}

From the Table 2: Demographic Analysis of respondents it can be seen that the study is being conducted on total 150 respondents out of which 50\% faculty members are from State Run Universities of Punjab and 50\% faculty members are from Private Universities of Punjab. Out of 150 respondents, 54.7\% are females and $45.3 \%$ are males. So, the number females are more than males in this study. Among the age group, $21.3 \%$ faculty members are below 30 years of age, $63.3 \%$ are between 30 - 40 years, $12.7 \%$ are 41 - 50 years and $2.7 \%$ are above 50 years of age. It is observed that the maximum number of respondents is between the age group of 30-40 years. 56.7\% respondents are married and $43.3 \%$ respondents are unmarried. Married faculty members are more in number as compared to unmarried ones. $79.3 \%$ faculty members have doctorate as their educational qualification, 15.3\% are postgraduates, and 5.3\% are Master of Philosophy (MPhil). This shows that maximum number of faculty members is Doctorate which a very good sign for the learning and development of the students, University as society at large. 60.7\% respondents are Assistant Professors, 32.7\% are Associate Professors and $6.7 \%$ are professors. So, it is observed that maximum faculty members are designated as Assistant Professors. 23.3\% respondents were serving the present University from more than 10 years, $30.7 \%$ have served for $7-10$ years, $24 \%$ have served for 2 - 6 years and $22 \%$ have served for less than 2 years. This shows that the maximum number of faculty members have served the present University for 7-10 years. The total experience of $16.7 \%$ respondents is below 5 years, $35.3 \%$ respondents are 5 - 10 years and $48 \%$ respondents have total experience of more than 10 years. Here it can be said that maximum number of faculty members have more than 10 years of total experience which is an indication that the students are being taught by experienced faculty members. 


\section{T-Test between Status Run and Private Universities of Punjab and Variables Related to Work Environment}

In order to understand whether there is any significant difference between mean of different types of Universities and variables related to work environment, independent sample T-test is carried out on 5 percent level of significance.

The null hypothesis for this is:

H01: There is no significant difference between Universities and variables related to Work Environment.

Table 3: T-test between State Run and Private Universities of Punjab and Variables Related to Work Environment

\begin{tabular}{|c|c|c|c|c|}
\hline \multirow{3}{*}{ Statements } & \multicolumn{4}{|c|}{ T-test for Equality of Means } \\
\hline & \multirow[b]{2}{*}{$\mathbf{T}$} & \multirow{2}{*}{$\begin{array}{l}\text { Sig.(P) } \\
\text { Value }\end{array}$} & \multicolumn{2}{|c|}{ Mean } \\
\hline & & & $\begin{array}{l}\text { State } \\
\text { Run }\end{array}$ & $\begin{array}{l}\text { Privat } \\
\text { e }\end{array}$ \\
\hline $\begin{array}{l}\text { I was oriented/ inducted with the job when I joined this } \\
\text { University. }\end{array}$ & 1.908 & 0.058 & 3.68 & 4.01 \\
\hline University goals and strategies are clearly communicated to me. & 2.936 & 0.004 & 3.36 & 3.85 \\
\hline $\begin{array}{l}\text { The rules, regulations and policies in the University are } \\
\text { transparent. }\end{array}$ & 2.810 & 0.006 & 3.44 & 3.92 \\
\hline $\begin{array}{l}\text { The suggestions given by the faculty members are being valued in } \\
\text { the University. }\end{array}$ & 3.350 & 0.001 & 3.4 & 3.93 \\
\hline $\begin{array}{l}\text { I am satisfied with how I am involved in decisions concerning my } \\
\text { work. }\end{array}$ & 3.156 & 0.002 & 3.43 & 3.93 \\
\hline I am consulted on important matters that affect my job. & 3.772 & 0.000 & 3.31 & 3.95 \\
\hline I feel that the University cares for my needs appropriately. & 4.649 & 0.000 & 3.27 & 4.04 \\
\hline The disciplinary procedure in the University is acceptable to me. & 3.090 & 0.002 & 3.53 & 4.07 \\
\hline $\begin{array}{l}\text { I feel that the contributions of the faculty members are } \\
\text { appropriately recognised }\end{array}$ & 3.957 & 0.000 & 3.39 & 4.05 \\
\hline $\begin{array}{l}\text { The work is distributed evenly amongst all faculty members of the } \\
\text { same department. }\end{array}$ & 4.019 & 0.000 & 3.33 & 4.04 \\
\hline $\begin{array}{l}\text { Men and Women are provided with equal career opportunities in } \\
\text { the University. }\end{array}$ & 1.380 & 0.170 & 3.87 & 4.11 \\
\hline The faculty members are treated with due respect. & 0.799 & 0.425 & 3.85 & 3.99 \\
\hline I am satisfied with the team spirit in the work environment. & 2.684 & 0.008 & 3.55 & 4.04 \\
\hline My job is guaranteed as long as I want to remain in the University. & 0.824 & 0.411 & 3.92 & 4.05 \\
\hline
\end{tabular}

From the above table 3 it is clear that there is significant difference between the Universities on the statement "University goals and strategies are clearly communicated to me" as the Sig (P) value is less than 0.05 and is 0.004 so the null hypothesis for this statement will be rejected and the alternative hypothesis will be accepted. Further as the mean 3.36 of State Run University is less as compared to mean 3.85 of Private University so it is clear that faculty members of Private University have more agreed with the clear communication of University goals and strategies. Next there is significant difference between the Universities on the statement "The rules, regulations and policies in the University are transparent" as the Sig $(\mathrm{P})$ value is less than 0.05 and is 0.006 so the null hypothesis for this statement will be rejected and the alternative hypothesis will be accepted. Further as the mean 3.44 of State Run University is less as compared to mean 3.92 of Private University so it is clear that faculty members of Private University have more agreed with the transparency of rules, regulations and policies in the University. Next there is significant difference between the Universities on the statement "The suggestions given by the faculty members are being valued in the University" as the Sig (P) value is less than 0.05 and is 0.001 so the null hypothesis for this statement will be rejected and the alternative hypothesis will be accepted. Further as the mean 3.4 of State Run University is less as compared to mean 3.93 of Private University so it is 
clear that faculty members of Private University have more agreed with the value given to the suggestions given by the faculty members. Further next there is significant difference between the Universities on the statement "I am satisfied with how I am involved in decisions concerning my work" as the Sig (P) value is less than 0.05 and is 0.002 so the null hypothesis for this statement will be rejected and the alternative hypothesis will be accepted. Further as the mean 3.43 of State Run University is less as compared to mean 3.93 of Private University so it is clear that faculty members of Private University have more agreed with satisfaction related to involvement in decision-making. Next there is significant difference between the Universities on the statement "I am consulted on important matters that affect my job" as the Sig (P) value is less than 0.05 and is 0.000 so the null hypothesis for this statement will be rejected and the alternative hypothesis will be accepted. Further as the mean 3.31 of State Run University is less as compared to mean 3.95 of Private University so it is clear that faculty members of Private University have more agreed with the consultation on important matters that affects the job. Further next there is significant difference between the Universities on the statement "I feel that the University cares for my needs appropriately." as the Sig (P) value is less than 0.05 and is 0.002 so the null hypothesis for this statement will be rejected and the alternative hypothesis will be accepted. Further as the mean 3.27 of State Run University is less as compared to mean 4.04 of Private University so it is clear that faculty members of Private University have more agreed with the needs being cared appropriately. Next there is significant difference between the Universities on the statement "The disciplinary procedure in the University is acceptable to me" as the Sig (P) value is less than 0.05 and is 0.000 so the null hypothesis for this statement will be rejected and the alternative hypothesis will be accepted. Further as the mean 3.53 of State Run University is less as compared to mean 4.07 of Private University so it is clear that faculty members of Private University have more agreed with the acceptance of disciplinary procedure in the university. Next there is significant difference between the Universities on the statement "I feel that the contributions of the faculty members are appropriately recognised" as the Sig (P) value is less than 0.05 and is 0.00 so the null hypothesis for this statement will be rejected and the alternative hypothesis will be accepted. Further as the mean 3.39 of State Run University is less as compared to mean 4.05 of Private University so it is clear that faculty members of Private University have more agreed with the recognition received for their contribution. Next there is significant difference between the Universities on the statement "The work is distributed evenly amongst all faculty members of the same department." as the Sig (P) value is less than 0.05 and is 0.00 so the null hypothesis for this statement will be rejected and the alternative hypothesis will be accepted. Further as the mean 3.33 of State Run University is less as compared to mean 4.04 of Private University so it is clear that faculty members of Private University have more agreed with the even distribution of work among all faculty members of same department. Lastly, there is significant difference between the Universities on the statement "I am satisfied with the team spirit in the work environment" as the Sig (P) value is less than 0.05 and is 0.008 so the null hypothesis for this statement will be rejected and the alternative hypothesis will be accepted. Further as the mean 3.55 of State Run University is less as compared to mean 4.04 of Private University so it is clear that faculty members of Private University have more agreed with the team spirit in the work environment.

From the above table 3 it is clear that there is no significant difference between the Universities on the statement, "I was oriented/inducted with the job when I joined this University", "Men and Women are provided with equal career opportunities in the University", "The faculty members are treated with due respect." and "My job is guaranteed as long as I want to remain in the University" as the Sig. (P) value in all the statements of variables related to work environment is more than 0.05 , so the null hypothesis for these statements will be accepted and the alternative hypothesis will be rejected. 
For statement "I was oriented/inducted with the job when I joined this University" the mean 3.68 of State Run University is less as compared to mean 4.01 of Private University so it is clear that faculty members of Private University have more agreed with conducting of orientation/induction programme at the time of joining as compared to the faculty members of State Run University. For statement "Men and Women are provided with equal career opportunities in the University" the mean 3.87 of State Run University is less as compared to mean 4.11 of Private University so it is clear that faculty members of Private University have more agreed with the provision of equal opportunities to both men and women. For statement "The faculty members are treated with due respect" the mean 3.85 of State Run University is less as compared to mean 3.99 of Private University so it is clear that faculty members of Private University have more agreed with the treatment of faculty members with due respect. For statement "My job is guaranteed as long as I want to remain in the University" the mean 3.92 of State Run University is less as compared to mean 4.05 of Private University so it is clear that faculty members of Private University have more agreed with the job security in the university as compared to State Run University.

\section{SUGGESTIONS AND RECOMMENDATIONS}

The research findings provide an understanding of the reasons for job dissatisfaction among the faculty members related to work environment. The education administrators need to work on the following variables of work environment to make the work environment more supportive and to maximise the satisfaction level among the faculty members.

- Orientation/induction programme should be organised for the new faculty members to overcome the initial uneasiness, anxiety and hesitation. The Universities should try their level best to make the new faculty member comfortable so that he can give his best towards his job.

- The university should properly communicate the goals, strategies, rules, regulation and policies to their faculty members so that they can have a clear view of the path to be followed to achieve the university goals and to avoid any kind of misunderstanding in following the university strategies, rules, regulations and policies.

- In order to satisfy and motivate the faculty members it is very essential for the universities to allow the faculty members to participate in decision making concerning their work. So it is essential to involve and consult the faculty members in decision making and their decisions should be considered.

- In order to build growth centred environment in the universities, the management should give proper recognition to the positive contribution made by the faculty members.

- The work should be distributed evenly amongst all faculty members of the same department and equal career opportunities should be provided because a feeling of partiality and biasness hinders the performance.

- It is very important that the faculty members who are working in the universities should be given due respect and their needs should be taken care off because if the teachers are not respected by the management and their needs are not considered they will lose interest and they will not give their best performance.

- Team Spirit is a significant variable of work environment because it helps to boost motivation among the faculty members.

- The faculty members should have a sense of job security because if they fear about their jobs they will not be able to show their sincerity and commitment towards their job and their satisfaction level will drop. 


\section{CONCLUSIONS}

Working environment has a significant impact on the satisfaction level of employees in the organisation. In the competitive business world only financial benefits are not sufficient for the employees to show efficient performance. However, they need both financial and non financial rewards to achieve organisational goals. This research paper has a lot of contribution towards the welfare of the society as the findings create an understanding about the significance of supportive work environment for the satisfaction of faculty members of the universities who are working hard to shape the future of a nation. Appropriate measures should be taken by the universities to improve the satisfaction level of the faculty members and enhance employee retention.

\section{ACKNOWLEDGEMENT}

I would like to convey my profound gratitude to Dr. Ramandeep Saini, Director Principal (officiating) Chandigarh Business School of Administration, Dean International Affairs, Chandigarh Group of Colleges (CGC), Landran, Mohali, Punjab, my research supervisor for her valuable guidance which has always been a great help in my research work. Her willingness to give her precious time out of her busy schedule is very much appreciable.

I would also like to extend my sincere gratitude to Dr. Satinder Pal Singh, Professor USB, Chandigarh University, Gharaun, Mohali, Punjab, for helping me in the analysis of data.

I would also like to thank various universities for allowing me to collect data from the faculty members of different departments. I am also grateful to the faculty members who shared their satisfaction level related to work environment.

My special thanks to Chandigarh Group of Colleges (CGC), Landran, Mohali, Punjab for organising an online International Conference during the time of pandemic and giving the researchers an opportunity to participate and publish their research papers in renowned journals.

\section{(CHANJYOT KAUR)}

\section{REFERENCES}

1. Aiken L, Clarke S, Sloane D. Hospital Staffing, Organizational Support and Quality of Care: Cross-National Findings. International Journal for Quality in Health Care 2002;50(5):87-94.

2. Cecilia Eberendu CA, Okon Peter Akpan EC, Ubani E, Ahaiwe J. A Methodology for the Categorisation of Software Projects in Nigeria Based on Performance. Asian Journal of Research in Computer Science 2018;1(4):1-9.

3. Sharma J, Dhar RL, Tyagi A. Stress as a Mediator between Work-family Conflict and Psychological Health among the Nursing Staff: Moderating Role of Emotional Intelligence. Applied Nursing Research 2016;30:268-275.

4. Arnetz B. Staff Perception of the Impact of Health Care Transformation on Quality of Care. International Journal for Quality in Health Care 1999;11(4):345-351.

5. Lane K, Esser J, Holte B, Anne MM. A Study of Nurse Faculty Job Satisfaction in Community Colleges in Florida. Teaching and Learning in Nursing 2010;5(1):16-26.

6. Mwendwa P, McAuliffe E, Uduma O, Masanja H, Mollel H. The Impact of Supportive Supervision on the Implementation of HRM Processes; a Mixed-Methods Study in Tanzania. Health Systems and Policy Research 2017;4(1):1-9. 
7. Chen SH, Yang CC, Shiau JY, Wang HH. The Development of an Employee Satisfaction Model for Higher Education. The TQM Magazine 2006;18(5):484-500.

8. Castillo JX, Cano J. Factors Explaining Job Satisfaction among Faculty. Journal of Agricultural Education 2004;45(3):65-74.

9. Munhurrun PR, Naidoo P, Bhiwajee SDL. Employee Perceptions of Service Quality in a Call Centre. Managing Service Quality 2009;19(5):541-557.

10. Buhai S, Cottini E, Nielseny N. The impact of Workplace Conditions on Firm Performance. Working Paper 2008:8-13, University of Aarhus, Aarhus School of Business, Department of Economics.

11. Srivastava AK. Effect of Perceived Work Environment on Employees Job Behaviour and Organizational Effectiveness. Journal of the Indian Academy of Applied Psychology 2008;34(1):47-55.

12. Baah K, Amoako GK. Application of Frederick Herzberg's Two-Factor Theory in Assessing and Understanding Employee Motivation at Work: a Ghanaian Perspective. European Journal of Business and Management 2011;3(9):1-8.

13. Chandrasekar K. Workplace Environment and Its Impact Organizational Performance in Public Sector organizations. International Journal of Enterprise Computing and Business Systems 2011;1(1):1-19.

14. Kamarulzaman N, Saleh A, Hashim S, Hashim H, Abdul-Ghani A. An Overview of the Influence of Physical Office Environments towards Employee. Procedia Engineering 2011;20:262-268.

15. Cottini E, Ghinetti P. Working Conditions, Lifestyles and Health. University of Aarhus, Department of Economics 2012.

16. Mattson E, Melder JD, Horowitz J. Workplace Environment And The Likelihood To Participate In Deviant Behaviour. Sentience 2016;14:24-26.

17. Bhatti K. The Mediation Model of Interrelationships among 4 C's of Work Environment, Employee Performance and Organisational Performance in Pakistani Organisations. Asia Proceedings of Social Sciences 2018;2(3):176-180.

18. Leblebici D. Impact of Workplace Quality on Employee's Productivity: Case Study of a Bank in Turkey. Journal of Business Economics 2012;1(1):38-49.

19. Naharuddin N, Sadegi M. Factors of Workplace Environment that Affect Employees Performance: A Case Study of Miyazu Malaysia. International Journal of Independent Research and Studies 2013;2(2):66-78.

20. Sarode AP, Shirsath M. The Factors Affecting Employee Work Environment and its Relation with Employee Productivity. International Journal of Science and Research 2014;3(11):2735-2737.

21. Awan AG, Tahir MT. Impact of Working Environment on Employee's Productivity: A Case Study of Banks and Insurance Companies in Pakistan. European Journal of Business and Management 2015;7(1):329-345.

22. Mbembati NA, Mwangu M, Muhondwa E, Leshabari MM. Performance Indicators for Quality in Surgical and Laboratory Services At Muhimbili National Hospital (MNH) in Tanzania. East African Journal of Public Health 2008;5(1):13-16.

23. W.Porter RM. Motivation and Work Behavior. 4th ed. McGraw-Hill;1975.

24. Gary A, Yukl K. Organisational Behaviour and Personnel Psychology. 1st ed. Surjeet Publication;1988. 